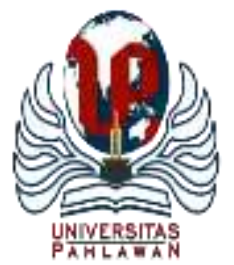

Edukatif : Jurnal Ilmu Pendidikan Volume 3 Nomor 6 Tahun 2021 Halm 3728 - 3739

EDUKATIF: JURNAL ILMU PENDIDIKAN

Research \& Learning in Education

https://edukatif.org/index.php/edukatif/index

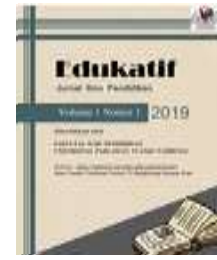

\title{
Pengembangan E-Modul Berbasis Flipbook Maker pada Mata Pelajaran Teknologi Perkantoran
}

\author{
Ferlinda Herdianti Widiana ${ }^{1 凶}$, Brillian Rosy $^{2}$ \\ Universitas Negeri Surabaya, Indonesia ${ }^{1,2}$ \\ E-mail : ferlinda.17080314103@ mhs.unesa.ac.id ${ }^{1}$, brillianrosy@unesa.ac.id ${ }^{2}$
}

\begin{abstract}
Abstrak
Tujuan dari penelitian ini pengembangan e-modul berbasis flipbook maker pada mata pelajaran teknologi perkantoran ini yaitu 1) untuk mengetahui proses pengembangan e-modul berbasis flipbook maker pada mata pelajaran teknologi perkantoran; 2) kelayakan pengembangan e-modul berbasis flipbook maker pada mata pelajaran teknologi perkantoran; 3) respons siswa terhadap pengembangan e-modul berbasis flipbook maker pada mata pelajaran teknologi perkantoran. Jenis metode penelitian ini adalah Research And Development dengan menggunakan model ADDIE yang terdapat lima tahapan yaitu Analysis (analisis data), Design (perencanaan), Development (pengembangan), Implementation (penerapan), Evaluation (evaluasi). Dalam penelitian ini instrumen yang digunakan yaitu terdiri dari lembar validasi ahli materi, media, bahasa dan hasil angket respons siswa SMKN 1 Sooko Mojokerto. Hal tersebut dibuktikan dengan hasil dari validasi ahli materi memperoleh persentase sebesar $85 \%$, ahli media sebesar $92 \%$, ahli bahasa sebesar $88 \%$ pengembangan e-modul berbasis flipbook maker pada mata pelajaran teknologi perkantoran memperoleh kategori "sangat layak" secara keseluruhan persentase yang diperoleh $88,33 \%$ dan hasil angket respons siswa memperoleh persentase $95,45 \%$. Sehingga dapat disimpulkan bahwa pengembangan e-modul berbasis flipbook maker pada mata pelajaran teknologi perkantoran sangat layak untuk diterapkan di SMKN 1 Sooko Mojokerto.
\end{abstract}

Kata Kunci: Modul elektronik, Flipbook Maker, Teknologi Perkantoran.

\begin{abstract}
The purpose of this research is the development of flipbook maker-based e-modules in office technology subjects, namely 1)to know the process of developing flipbook maker-based e-modules in office technology subjects; 2)feasibility of developing flipbook maker-based e-modules in office technology subjects; 3) student response to the development of flipbook maker-based e-modules in office technology subjects. This type of research method is Research And Development using the ADDIE model which has five stages, namely Analysis (data analysis), Design (planning), Development (development), Implementation (application), Evaluation (evaluation). In this study, the instrument used consists of expert validation sheets of materials, media, language and response results of SMKN 1 student Sooko Mojokerto. This is evidenced by the results of validation of material experts obtained a percentage of $85 \%$, media experts by $92 \%$, linguists by $88 \%$ of flipbook maker-based e-module development in office technology subjects obtained the category of "very decent" overall percentage obtained $88.33 \%$ and student response questionnaire results obtained a percentage of $95.45 \%$. So it can be concluded that the development of flipbook maker-based e-modules in office technology subjects is very feasible to apply in SMKN 1 Sooko Mojokerto.
\end{abstract}

Keywords: Electronic Module, Flipbook Maker, Office Technology.

Copyright (c) 2021 Ferlinda Herdianti Widiana, Brillian Rosy

$\triangle$ Corresponding author

Email : ferlinda.17080314103@mhs.unesa.ac.id

DOI : https://doi.org/10.31004/edukatif.v3i6.1265

ISSN 2656-8063 (Media Cetak)

ISSN 2656-8071 (Media Online)

Edukatif : Jurnal Ilmu Pendidikan Vol 3 No 6 Tahun 2021 p-ISSN 2656-8063 e-ISSN 2656-8071 


\section{PENDAHULUAN}

Pendidikan adalah suatu bentuk sarana mencapai pertumbuhan dan perkembangan bangsa. Melalui keberadaan pendidikan, seorang individu mampu menstimulus dirinya untuk memiliki kemampuan menghadapi setiap hal akibat hadirnya kemajuan IPTEK (Putra \& Anggraini, 2016). Menurut Asmi et al., ( 2018), "pendidikan dalam hal ini juga termasuk proses pembelajaran merupakan sebuah bentuk proses komunikasi yang diciptakan atau diwujudkan melalui kegiatan belajar mengajar oleh pengajar kepada peserta didik". Untuk mewujudkan pembelajaran efektif dan menyenangkan, maka perlu adanya bentuk komponen dalam proses belajar mengajar atau dikenal juga dengan modul. Menurut Praspita \& Rosy (2020), "bahan ajar merupakan suatu sarana proses belajar yang mampu mendorong atau membantu pendidik atau pelajar demi terlaksananya suatu proses pembelajaran".

Permasalahan pendidikan di Indonesia yaitu kurang tersedianya bahan ajar, Bahan ajar dipandang sebagai suatu hal yang krusial atau penting dalam proses atau kegiatan pembelajaran dengan tujuan untuk meningkatkan pembelajaran. Magdalena et al., (2020) "mengungkapkan "bahan ajar sekumpulan materi yang secara sistematis disusun sebagai media belajar mandiri sesuai dengan kurikulum yang berlaku". Pada dewasa ini, peran tenaga pendidik atau pengajar lebih mengarah kepada sebagai fasilitator dimana bertindak dalam mengarahkan serta membantu siswa dalam belajar.

Bahan ajar merupakan sarana pembelajaran yang dipergunakan dengan berbantu alat guna mempermudah penyampaian materi pada saat proses pembelajaran di sekolah. Hal tersebut akan mempermudahkan pengajar ketika pelaksanaan kegiatan mengajar di sekolah dan menjadi solusi untuk membuat peserta didik bersemangat ketika belajar. Fakta dilapangan menunjukkan bahwa dewasa ini, sebagian besar modul untuk pembelajaran dibuat dalam berbentuk modul cetak. Keberadaan modul cetak kerap memiliki sangat sedikit peminat terutama dikalangan remaja saat ini sebab dipandang terlalu monoton (Ricu Sidiq \& Najuah, 2020).

Menciptakan modul dalam bentuk yang lebih efisien dan menarik dapat menjadi salah satu cara agar siswa sekolah menengah menjadi lebih tertarik dan berminat dalam membaca modul sebab modul elektronik kerap dilengkapi dengan berbagai produk-produk interaktif seperti animasi, video, gambar dan audio. Perkembangan IPTEK di abad ke-21 mendukung proses belajar yang interaktif. Contohnya, beberapa media belajar berbasis teknologi dan komputer di abad ke-21 mulai banyak dimanfaatkan di kalangan akademik. Selaras dengan argumen yang dikemukakan oleh Karno, (2015) "E-learning dimanfaatkan ketika proses pembelajaran. Selain E-learning, modul digital merupakan media ajar yang muncul dari adanya perkembangan IPTEK". Syidiq \& Najuah (2020),"juga menyebutkan bahwa pada dasarnya pengembangan modul dalam hal ini sesuai dengan keberadaan banyaknya tantangan pada era disrupsi. Dengan kata lain, modul yang digunakan harus merupakan modul yang telah dikembangkan berdasarkan kemajuan IPTEK". Widyaningrum \& Patrikha (2021), mengemukakan bahwa "seiring dengan berkembangnya zaman, teknologi, dan media belajar, maka semakin banyak inovasi muncul dalam kegiatan belajar mengajar (KBM)".

Modul adalah bahan ajar yang berbentuk cetak dimana bahan ajar ini dirancang untuk siswa dalam kegiatan belajar mengajar secara mandiri. Pada hakikatnya, modul dipandang juga sebagai media pembelajaran mandiri sebab di dalam modul telah terdapat petunjuk dan cara untuk melaksanakan belajar sendiri bagi peserta didik. Hal ini berarti peserta didik mampu melaksanakan proses pembelajaran tanpa harus dibimbing oleh tenaga pengajar tertentu. Menurut (Susilo et al., 2016), dalam modul "bahasa, pola, dan karakteristik bahan ajar telah diatur seolah-olah bahasa pengajar yang digunakan untuk belajar mengajar. Dengan kata lain, media juga disebut sebagai bahan instruksional mandiri”.

Mata pelajaran Teknologi Perkantoran merupakan suatu bentuk mata pembelajaran baru yang terdapat dalam Kurikulum 2013 Revisi 2017 dimana mata pembelajaran ini dibagikan bagi siswa kelas X Otomatisasi dan Tata Kelola Perkantoran (OTKP). Berdasarkan Kompetensi Dasar ini, terdapat pembahasan mengenai 
interpretasi materi dalam mengkaji informasi yang berasal dari dunia maya atau internet sebagai bentuk upaya dalam menyangga pekerjaan kantor, siswa memiliki kesempatan untuk dapat menginterpretasikan dengan baik sumber atau asal informasi melalui internet dalam menyangga pekerjaan dan tanggung jawab perkantoran. Pada kompendium kelas X terkandung Kompetensi Dasar dalam membedah informasi yang berasal dari jagat maya untuk membantu tugas dan tanggungjawab pada pekerjaan kantor. Melalui proses belajar mengajar Teknologi Perkantoran atas Kompetensi Dasar ini pelajar bisa menginterpretasikan informasi yang bersumber dari dunia maya atau internet dalam mendukung pekerjaan atau tanggung jawab kantor, siswa juga mampu memecahkan permasalahan yang terdapat pada suatu pekerjaan dalam sebuah perusahaan (Citra \& Rosy, 2020).

Berdasarkan hasil observasi yang dilakukan oleh peneliti mengenai permasalahan pembelajaran yang terjadi di SMKN 1 Sooko Mojokerto kelas X OTKP 1 yakni ketika pembelajaran yang berlangsung pada mata pelajaran teknologi perkantoran memanfaatkan alat bantu berupa papan tulis, komputer, dan metode ceramah. Hasil wawancara yang dilakukan oleh peneliti guru mata pelajaran teknologi perkantoran menyatakan bahwa sebelumnya sudah ada bahan ajar yang berupa BSE (Buku Sekolah Elektronik) yang dipinjamkan oleh perpustakaan, namun karena jumlahnya yang sangat terbatas dan bahasa yang digunakan sulit dipahami siswa. Buku Sekolah Elektronik pada umunya tebal dan berat sehingga rendahnya minat siswa dalam membaca. Siswa lebih suka yang praktis dan efektif. Bahan ajar tersebut tidak bisa digunakan sewaktu-waktu oleh siswa dan dirasa kurang praktis. Buku pelajaran yang saat ini diperlukan inovasi agar mengikuti perkembangan dunia IPTEK dan akan memudahkan siswanya untuk belajar, disesuaikan disesuaikan dengan kurikulum yang ada di sekolah tersebut. Oleh karena dibutuhkan adanya pegembangan e-modul berbasis flipbook maker pada mata pelajaran teknologi perkantoran sebagai solusi, supaya siswa dapat memiliki bahan belajar yang mandiri yang dapat digunakan dimana saja dan siswa dapat aktif serta mampu berfikir ilmiah dalam proses pembelajaran.

Proses pembelajaran pada hakikatnya merupakan suatu kegiatan atau proses dimana terdapat kegiatan mengatur maupun mengorganisasikan kondisi lingkungan yang terdapat disekitar siswa atau peserta didik dimana proses tersebut mampu menghasilkan serta menjadi motivasi bagi peserta didik untuk melaksanakan proses belajar. Menurut Pane \& Dasopang, (2017), “pembelajaran juga digambarkan sebagai suatu kegiatan atau proses dimana tenaga pengajar memberikan bantuan maupun bimbingan bagi siswa atau peserta didik didalam melaksanakan kegiatan belajar. Pada dasarnya, proses pembelajaran dan belajar merupakan kegiatan utama dalam pendidikan". Hanafy, (2014) mengatakan bahwa "pembelajaran adalah proses tukar informasi dari pengajar ke peserta didik yang didukung dengan fasilitas menunjang".

Secara nasional, pembelajaran ditinjau sebagai proses interaksi yang dilakukan oleh peserta didik atau siswa, tenaga pengajar atau pendidik serta komponen-komponen penting lainnya seperti peralatan belajar dan lain sebagainya. Untuk menunjang proses pembelajaran, maka diperlukan sebuah media belajar yang disebut sebagai bahan ajar.

Menurut (Rahmi, 2018), E-modul ialah suatu bentuk media belajar mandiri yang disusun dalam bentuk digital dimana hal ini bertujuan sebagai upaya untuk dalam mewujudkan kompetensi pembelajaran yang ingin dicapai selain itu juga untuk menjadikan peserta didik menjadi lebih interaktif dengan menggunakan aplikasi tersebut. Menurut (Sugianto et al., 2013), ialah suatu bentuk media yang digunakan dan dimanfaatkan dalam proses kegiatan belajar mengajar yang mandiri dimana hal ini memiliki tujuan dalam memperoleh keterampilan dalam pembelajaran yang diinginkan dimana pembelajaran tersebut disusun dalam formasi elektronik yang mencakup diantaranya yaitu animation, audio, navigation yang mana hal tersebut membentuk peserta didik untuk menjadi lebih interaktif dengan menggunakan aplikasi tersebut. Hal serupa didukung dengan penelitian yang terdahulu (Fausih, 2015) terkait dengan penelitian pengembangan e-modul, didapatkan beberapa hasil penelitian yang selaras dengan penelitian pengembangan e-modul yaitu, menyatakan bahwa penggunaan e-modul pada siswa jurusan teknik komputer jaringan di SMK Negeri 1 Labang dapat 
meningkatkan hasil belajar siswa, ini terbukti oleh hasil uji t dengan diperolehnya data hitung Thitung lebih besar dari Ttabel.

Berkaitan dengan ini penulis ingin mengembangkan sebuah e-modul yang sedikit berbeda dengan penelitian yang tersebut yaitu dengan menerapkan salah satu model pembelajaran kurikulum 2013 dalam emodul, yaitu discovery learning. Penelitian yang akan penulis kembangkan ini yaitu "Pengembangan e-modul berbasis flipbook maker pada mata pelajaran teknologi perkantoran".

Berdasarkan beberapa pendapat para ahli, e-modul adalah bentuk kompilasi materi sebagai bahan ajar untuk siswa dengan efektif dan efisien secara mandiri, karena didalamnya memuat suatu pedoman dalam proses belajar mandiri dan sendiri. Artinya, siswa bisa melaksanakan kegiatan belajar mengajarnya secara mandiri kendatipun tidak dampingi pengajar. Menurut (Fitri Nurmayanti, Fauzi Bakri, 2015), "modul pembelajaran elektronik memiliki sifat-sifat tertentu seperti mudah digunakan, adaptif, dan konsisten". Salah satu alat atau instrumen lunak yang dirancang dengan tujuan untuk mengkonversi file PDF kedalam wujud digital book atau halaman balik publikasi yaitu Kvisoft Flipbook Maker. Perangkat atau instrumen lunak ini bisa mengkonversikan bentuk file PDF sehingga lebih memikat bagaikan sepatutnya sebuah buku.

Selain itu, menurut Sugianto et al., (2013), "Kvisoft Flipbook Maker juga memiliki kemampuan untuk membentuk file PDF seperti selayaknya sebuah majalah, digital magazine, flipbook, catatan atau brosur suatu perusahaan, catatan atau brosur digital serta lain sebagainya. Penggunaan media flipbook maker diharapkan dapat membentuk suatu media pembelajaran seperti e-modul dimana hal media ini diinginkan dapat membuat siswa senang dalam proses belajar mengajar". Flipbook maker pada dasarnya merupakan bentuk aplikasi atau software dalam membentuk buku, majalah, atau jurnal digital. Penelitian serupa dilakukan oleh Rahim (2017) dimana bahwa hasil penelitian menunjukkan modul elektronik yaitu dapat untuk meningkatkan keterampilan berpikir kritis serta memotivasi siswa karena e-modul sudah memiliki kriteria yang sangat baik. Hal ini didukung dengan peneliti (Fitrayani \& Hunaepi, 2016)ialah pengembangan electronic modul yang didukung dengan audio serta video berbasis smartphone berplatform android bisa menjadi sebagai bahan ajar mandiri untuk peserta didik, dan pendidiknya hanya bertugas sebagai fasilitator proses kegiatan belajar mengajar. Hal tersebut juga didukung oleh (Prastowo, 2015:14) seiring dengan perkembangan teknologi yang semaki canggih, format modul berubah dari berbentuk cetak menjadi format elektronik yang biasa juga disebut electronic modul(e-modul). Berdasarkan penelitian terdahulu tersebut, peneliti dapat menyimpulkan bahwa $e$ modul digital flipbook dapat dijadikan solusi yang tepat pada kondisi paragdima pembelajaran berbasis digital agar siswa mampu berpikir kritis serta menemukan konsep secara kemandirian.

Berdasarkan hasil pemaparan diatas pegembangan e-modul dalam pembelajaran teknologi perkantoran diperlukan sebagai suatu upaya agar siswa dapat memahami dan menguasai hal praktis serta dapat belajar mandiri melalui e-modul terutama pada masa pandemi saat ini dimana pembelajaran online dengan penggunaan e-modul dipandang solusi yang efektif bagi siswa. Oleh karena itu peneliti tertarik melakukan penelitian dengan judul "Pengembangan E-modul Berbasis Flipbook Maker pada Mata Pelajaran Teknologi Perkantoran" kelas X OTKP 1 SMKN 1 Sooko Mojokerto dan bagaimana guru dapat memanfaatkan E-modul dalam pembelajarannya.

Dari penjelasan diatas dapat ditentukan rumusan masalah yang diangkat dalam penelitian ini adalah: (1) Bagaimana proses pengembangan e-modul berbasis flipbook maker pada mata pelajaran teknologi perkantoran?; (2) Bagaimana kelayakan pengembangan e-modul berbasis flipbook maker pada mata pelajaran teknologi perkantoran?; (3) Bagaimana respons siswa terhadap pengembangan e-modul berbasis flipbook maker pada mata pelajaran teknologi perkantoran.

Tujuan penelitian ini antara lain: (1) Proses pegembangan e-modul berbasis flipbook maker pada mata pelajaran teknologi perkantoran; (2) Kelayakan pegembangan e-modul berbasis flipbook maker pada mata pelajaran teknologi perkantoran; (3) Respons siswa terhadap pengembangan e-modul berbasis flipbook maker pada mata pelajaran teknologi perkantoran. 
3732 Pengembangan E-Modul Berbasis Flipbook Maker pada Mata Pelajaran Teknologi Perkantoran - Ferlinda Herdianti Widiana, Brillian Rosy

DOI: https://doi.org/10.31004/edukatif.v3i6.1265

\section{METODE PENELITIAN}

Menurut (Sugiyono, 2016), metode yang digunakan untuk mengembangkan media dan menguji keefektifan produk adalah metode penelitian Research and Development. pendekatan ADDIE digunakan untuk mengembangkan media pembelajaran. Subjek dalam penelitian ini adalah siswa kelas X OTKP 1 SMKN 1 Sooko Mojokerto.

Ada 5 tahap yang dilakukan untuk mengembangkan Flipbook Maker. Tahap pertama adalah tahap Analysis. Tahap Analysis termasuk di dalamnya persyaratan dan kebutuhan siswa yang diobservasi sebelum membuat e-modul. Dalam tahap ini, juga perlu dilakukan analisis kinerja dan kebutuhan. Tahap kedua adalah Tahap Design. Tahap ini bertujuan untuk membuat rancangan e-modul berbasis flipbook maker. Hal ini meliputi cara membuat perangkat pembelajaran, menyusun KBM atau kegiatan pembelajaran, dan bahan ajar. Kemudian, tahap ketiga adalah Tahap Development. Rancangan e-modul diuji coba untuk memberikan suatu prototipe awal. Setelah diuji coba, e-modul harus diuji validasi oleh para ahli. Pada tahapan keempat yaitu Tahap Implementation, e-modul diuji coba secara terbatas pada 24 siswa kelas X OTKP 1 SMKN 1 Sooko Mojokerto. Tahapan terakhir adalah Tahap Evaluation. Tujuan evaluasi adalah untuk melihat keefektifan emodul berbasis flipbook maker pada 24 siswa kelas X OTKP pada mata pelajaran teknologi perkantoran. Lalu, tahap validasi dilakukan oleh ahli materi atau validator yang cukup menguasai tentang media dan bahasa. Dengan kata lain, modul diuji kelayakannya sebagai media pembelajaran khususnya mata pelajaran teknologi perkantoran.

Total subjek yang berjumlah ada 34 siswa kelas X jurusan OTKP. Namun, untuk uji coba, peneliti mengambil sampel penelitian sebanyak 24 siswa. Sehingga, peneliti menentukan 24 sampel dari untuk uji coba. karena sesuai dengan evaluasi kelompok kecil. Sadiman (2014:185) berpendapat "sampel yang diambil lebih dari 20 sampel, akan ada kelebihan data dalam sebuah penelitian dengan metode riset dan pengembangan.Pengembangan e-modul berbasis flipbook maker pada mata pelajaran teknologi perkantoran adalah objek dalam penelitian ini dan dilakukan di SMKN 1 Sooko Mojokerto.

Instrumen yang digunakan adalah lembar validasi ahli dan lembar angket respons siswa. Pada lembar validasi ahli materi, media dinilai oleh Guru Mata Pelajaran Teknologi Perkantoran kelas X di SMKN 1 Sooko Mojokerto. Sedangkan, untuk lembar validasi ahli bahasa dilakukan oleh Guru Mata Pelajaran Bahasa Indonesia SMKN 1 Sooko Mojokerto. Kemudian, untuk menilai kelayakan modul siswa kelas X OTKP, skala Likert digunakan dalam penilaian lembar validasi. Tabel 1 adalah skala penilaian validasi e-modul dan Tabel 2 adalah skala angket respons siswa pada e-modul yang disajikan sebagai berikut:

Tabel 1. Skala Penilaian Validasi E-modul

\begin{tabular}{cc}
\hline Kriteria & Skor \\
Sangat Baik & 5 \\
Baik & 4 \\
Sedang & 3 \\
Tidak Baik & 2 \\
Sangat Tidak Baik & 1 \\
\hline Sumber: Riduwan, 2015:13) \\
Tabel 2. Skala Angket Respons Peserta Didik \\
\hline Kriteria & Skor \\
\hline Sangat Baik & 5 \\
\hline Baik & 4 \\
\hline
\end{tabular}


3733 Pengembangan E-Modul Berbasis Flipbook Maker pada Mata Pelajaran Teknologi Perkantoran - Ferlinda Herdianti Widiana, Brillian Rosy

DOI: https://doi.org/10.31004/edukatif.v3i6.1265

\begin{tabular}{cl}
\hline Sedang & 3 \\
\hline Tidak Baik & 2 \\
\hline Sangat Tidak Baik & 1 \\
\hline (Sumber: Riduwan, 2015:13) &
\end{tabular}

\section{Teknik Analisis Data}

Teknik analisis data diperoleh berdasarkan lembar validasi e-modul ahli materi, media, dan bahasa. Kemudian, data yang diperoleh dianalisis secara deskriptif-kuantitatif sebagai berikut:

\section{Analisis Validasi E-modul Ahli Materi}

Rumus untuk menghitung persentase hasil validasi e-modul dari ahli materi berdasarkan Riduwan (2015:15):

Persentase $(\%)=\frac{\text { Jumlah Skor hasil Validasi }}{\text { Skor tertinggi }} \times 100$

\section{Analisis Validasi E-modul Ahli media}

Persentase analisis validasi e-modul dari ahli media dihitung dengan rumus (Riduwan, 2015:15):

Persentase $(\%)=\frac{\text { Jumlah Skor hasil Validasi }}{\text { Skor tertinggi }} \times 100$

\section{Analisis Validasi E-modul Ahli Bahasa}

Persentase analisis validasi e-modul dari ahli bahasa menggunakan rumus (Riduwan, 2015:15):

Persentase $(\%)=\frac{\text { Jumlah Skor hasil Validasi }}{\text { Skor tertinggi }} \times 100$

Kategori hasil persentase validasi e-modul dengan kriteria penilaian skala Likert pada Tabel 3. Hasil e-modul dianggap layak apabila persentasenya sebesar $\geq 61 \%$ dengan kategori layak.

Tabel 3. Kriteria Penilaian Skor Validasi E-modul

\begin{tabular}{cc}
\hline Kriteria & Persentase (\%) \\
\hline Sangat Tidak Layak & $0-20$ \\
\hline Tidak Layak & $21-40$ \\
\hline Cukup Layak & $41-60$ \\
\hline Layak & $61-80$ \\
\hline Sangat Layak & $81-100$ \\
\hline (Sumber: Riduwan, 2015:13)
\end{tabular}

\section{Analisis Evaluasi Siswa}

Perhitungan analisis lembar evaluasi siswa menggunakan rumus (Riduwan, 2015:15):

Persentase $(\%)=\frac{\text { Jumlah Skor hasil Validasi }}{\text { Skor tertinggi }} \times 100$

Berdasarkan persentase angket evaluasi siswa, kriteria evaluasi siswa dikategorikan dalam beberapa kriteria dari skala Likert seperti pada Tabel 4. Apabila persentase modul sebesar $\geq 61 \%$, maka modul dianggap layak digunakan untuk siswa kelas X OTKP.

Tabel 4. Kriteria Persentase Skala Likert

\begin{tabular}{cc}
\hline Penilaian & $\begin{array}{c}\text { Kriteria } \\
\text { Interpretasi }\end{array}$ \\
\hline $0 \%-20 \%$ & Sangat Lemah \\
\hline
\end{tabular}




\begin{tabular}{cc}
\hline $21 \%-40 \%$ & Lemah \\
\hline $41 \%-60 \%$ & Cukup \\
\hline $61 \%-80 \%$ & Kuat \\
\hline $81 \%-100 \%$ & Sangat Kuat \\
\hline
\end{tabular}

(Sumber: Riduwan, 2015:13)

\section{HASIL DAN PEMBAHASAN PENELITIAN}

Hasil dan pembahasan dalam penelitian ini ditujukan untuk menjawab rumusan masalah dari pengembangan modul digital berbasis Flipbook Maker. Berikut adalah proses pengembangan e-modul berbasis flipbook maker pada mata pelajaran teknologi perkantoran kelas X OTKP 1 SMKN 1 Sooko Mojokerto, proses pegembangan e-modul, dan kelayakan e-modul dan respons siswa.

\section{Proses Pengembangan E-modul Berbasis Flipbook Maker pada Mata Pelajaran Teknologi Perkantoran}

Kesan siswa dalam menggunakan e-modul berbasis Flipbook Maker pada beberapa siswa kelas X OTKP 1 SMKN 1 Sooko Mojokerto yang diwawancarai menyatakan bahwa "Setiap KBM, materi didapat hanya dari guru dengan media PPT (Power Point), buku paket, dan praktik pada laboratorium". Berdasarkan wawancara siswa, siswa merasa perlu mendapatkan materi tambahan agar dapat belajar mandiri dan lebih menguasai Teknologi Perkantoran. E-modul berbasis Flipbook Maker sangat cocok dikembangkan bagi siswa SMK jurusan OTKP. Menurut Gunadharma (dalam Sugianto 2013), modul elektronik yaitu penggabungan informasi secara struktural dan dirancang semenarik mungkin. Pengembangan e-modul menggunakan Kvisoft Flipbook Maker mendukung pengguna untuk editing, menambahkan video, gambar, audio, atau navigasi layaknya buku asli (Ihsan, 2014).

\section{Tahap Analisis (Analysis) \\ Analisis Kinerja}

Peserta didik di SMKN 1 Sooko Mojokerto, khususnya pada kelas X OTKP 1, masih merasa bingung untuk memahami Teknologi Perkantoran dan kebanyakan dari siswa tidak dapat belajar mandiri. Dari analisis kinerja, hal ini dipengaruhi oleh KBM yang terkesan satu arah dimana para siswa diminta untuk menulis materi dan praktik saat kegiatan belajar mengajar.

\section{Analisis Kebutuhan}

SMKN 1 Sooko Mojokerto membutuhkan bahan ajar berupa e-modul karena mata pelajaran teknologi perkantoran merupakan pelajaran baru di kelas X. Untuk memanfaatkan sarana dan prasarana sekolah, laboratorium Administrasi Perkantoran di SMKN 1 Sooko Mojokerto dimanfaatkan sebagai sarana pengembangan e-modul berbasis flipbook maker. Peneliti memanfaatkan laboratorium Administrasi Perkantoran untuk memperoleh data yang dibutuhkan. Pada tahap analisis kebutuhan, dimana siswa lebih menykai bahan ajar yang inovatid dan kreatif yaitu seperti modul elektroni yang bukan hanya berupa teks serta gambar juga dipadukan dengan audio, serta animasi yang mendukung materi pembelajaran dengan penggunaan bahasa dalam e-modul yang mudah dipahami siswa. Tujuan dari e-modul ini yaitu mengetahu karakteristik siswa yang berbeda-beda yang dapat mempengaruhi pembelajaran, hal ini selaras dengan pandangan Prastowo (2015) yang menyatakan bahwa beberapa tujua modul yaitu untuk mengakomodasi kecepatan belajar siswa yang memiliki kecepatan tinggi akan menyelesaikan modul dengan cepat. 

Herdianti Widiana, Brillian Rosy

DOI: https://doi.org/10.31004/edukatif.v3i6.1265

\section{Tahap Perancangan (Design)}

Tahap perancangan dilakukan untuk merancang produk yang dikembangkan, isi produk, dan membuat instrumen penelitian. Langkah pertama yaitu membuat isi e-modul secara umum. Bagian awal e-modul berisi tampilan awal modul (cover), dan sampul sub judul. Sedangkan, untuk bagian isi, terdapat penjelasan materi, latihan soal (objektik \& essay), serta bagian penutup berisikan glosarium, dan daftar pustaka. Di dalam bagian uraian materi, peneliti merancang penyusunan materi dengan mengombinasikan materi, gambar \& ilustrasi. Pemilihan gambar diselaraskan dengan isi materi, bertujuan guna menguatkan pemahaman siswa. Bahan ajar ini menyuguhkan gambar, uraian materi secara detail tergolong dalam bahan ajar teknologi audio-visual menurut Seels \& Richey dalam Arsyad (2017:34). Setelah penyelesaian rancangan, peneliti akan membuat aplikasi Kvisoft Flipbook Maker dan membuat rancangan instrumen untuk divalidasi oleh para ahli.

\section{Tahap Pengembangan (Development)}

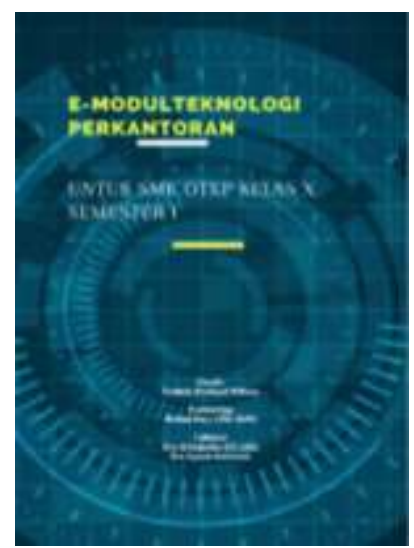

(Sumber: Diolah Peneliti, 2021)

Tahap ini memilih dan menentukan rancangan isi e-modul. E-modul berbentuk prototipe 1 akan ditelaah dari segi materi, media, dan bahasa. E-modul yang telah dikembangkan oleh peneliti kemudian mendapat ulas balik untuk uji kelayakan. Lalu, peneliti merevisi e-modul sesuai masukan dari para ahli. Langkah selanjutnya adalah proses validasi. Proses validasi dilakukan untuk uji kelayakan e-modul berbasis flipbook maker pada mata pelajaran teknologi perkantoran sebelum diimplementasikan pada siswa di SMKN 1 Sooko Mojokerto. Hasil validasi tersebut akan dianalisis secara kuantitatif atau dalam bentuk persentase. Dengan demikian, persentase hasil kelayakan e-modul berbasis flipbook maker dapat dinilai sesuai dengan kriteria.

\section{Tahap Implementasi (Implementation)}

E-modul yang telah divalidasi akan diuji coba secara terbatas pada 24 siswa kelas X OTKP SMKN 1 Sooko Mojokerto. Peneliti menyebarkan hasil dari e-modul yang telah disarankan oleh ahli validasi. Pertama, peneliti mempersiapkan e-modul yang akan diuji coba pada siswa. Penyebaran e-modul menggunakan flashdisk yang di copy and paste di setiap komputer di laboratorium Administrasi Perkantoran SMKN 1 Sooko Mojokerto. Setelah semua dipersiapkan dengan baik, siswa dapat menggunakan aplikasi pembelajaran dan peneliti mengobservasi penggunaan Flipbook Maker pada ke 24 siswa kelas X OTKP.

\section{Tahap Evaluasi (Evaluation)}

Tahap evaluasi sebagai tahap akhir dilakukan untuk meninjau penggunaan Flipbook Maker. Dari tahap evaluasi, para ahli materi, media, bahasa, dan angket respons siswa memberi penjabaran atas kelayakan $e$ modul dan mengevaluasi pengembangan e-modul berikutnya. 
3736 Pengembangan E-Modul Berbasis Flipbook Maker pada Mata Pelajaran Teknologi Perkantoran - Ferlinda Herdianti Widiana, Brillian Rosy

DOI: https://doi.org/10.31004/edukatif.v3i6.1265

\section{Kelayakan pengembangan E-modul berbasis Flipbook Maker pada Mata Pelajaran Teknologi Perkantoran}

Kelayakan e-modul berbasis flipbook maker pada mata pelajaran teknologi perkantoran dapat dilihat dari penilaian para validator dan uji coba terbatas yang disesuaikan dengan kriteria tertentu. Dari segi kelayakan materi, media divalidasi oleh Guru Mata Pelajaran Teknologi Perkantoran SMKN 1 Sooko Mojokerto. Sedangkan untuk validasi ahli bahasa oleh Guru Mata Pelajaran Bahasa Indonesia SMKN 1 Sooko Mojokerto. Hasil rata-rata ahli materi pada Tabel 5:

Tabel 5. Rekapitulasi Kelayakan E-modul

\begin{tabular}{lcl}
\hline Ahli & $\begin{array}{l}\text { Persentase } \\
(\boldsymbol{\%})\end{array}$ & Kategori \\
\hline Ahli Materi & 85 & Sangat Layak \\
\hline Ahli Media & 92 & Sangat Layak \\
\hline Ahli Bahasa & 88 & Sangat Layak \\
\hline Rata-rata & $88,33 \%$ & Sangat Layak
\end{tabular}

(Sumber:Diolah peneliti, 2021)

Berdasarkan komentar \& saran ahli materi e-modul yang sudah dibuat sudah sesuai dengan materi dan silabus hanya kurang dalam penulisan judul yang perlu dipertegas. Hasil ahli materi memperoleh persentase $85 \%$ dikategorikan sangat layak. Menurut Riduwan, (2015) yang menyebutkan bahwa apabila suatu data dikatakan layak mendapatkan hasil $\geq 61 \%$.Berdasarkan komentar \& saran ahli media cover e-modul sudah baik, jenis \& ukuran font jelas, gambar dalam e-modul sesuai. Hasil ahli media memperoleh persentase $92 \%$. Jadi dapat diartikan layak sesuai dengan kriteria interpretasi menurut Riduwan, (2015) dinyatakan layak apabila media memiliki persentase hasil $\geq 61 \%$ yang diperoleh. Berdasarkan komentar dan saran ahli bahasa, bahasa yang digunakan sudah baku, komunikatif, jelas, dan mudah dipahami. Hasil ahli bahasa memperoleh persentase $88 \%$ dikategorikan sangat layak sesuai dengan kriteria interpretasi menurut Riduwan, (2015) dinyatakan layak apabila persentase memili hasil memiliki persentase hasil $\geq 61 \%$ yang diperoleh. Secara keseluruhan, hasil persentase yang diperoleh adalah $88,33 \%$ dengan kategori sangat layak. Kelayakan tersebut ditinjau dari materi, media, dan bahasa dalam e-modul.

\section{Respons siswa kelas X OTKP 1 SMKN 1 Sooko Mojokerto terhadap Pengembangan E-modul Berbasis} Flipbook Maker pada Mata Pelajaran Teknologi Perkantoran.

Siswa diminta untuk mengisi lembar angket respons terhadap pengembangan e-modul berbasis Flipbook Maker. Dalam hal ini, siswa memberi tanggapan tentang penggunaan e-modul dengan basis Flipbook Maker. Berikut ini adalah pertanyaan angket respons siswa pada Tabel 6:

Tabel 6. Pertanyaan Angket Respons Peserta Didik

\begin{tabular}{lcc}
\hline \multicolumn{1}{c}{ Pertanyaan } & $\begin{array}{c}\text { Persentase } \\
(\mathbf{\%})\end{array}$ & Kriteria \\
\hline Uraian materi pembelajaran mudah dipahami & $70,4 \%$ & Layak \\
\hline Materi e-modul disajikan dengan jelas dan mudah diikuti & $80 \%$ & Sangat Layak \\
\hline
\end{tabular}




\begin{tabular}{lcc}
\hline $\begin{array}{l}\text { Isi materi dalam e-modul secara keseluruhan mampu menarik } \\
\text { minat siswa untuk belajar }\end{array}$ & $70,4 \%$ & Layak \\
\hline Bahasa yang digunakan dalam e-modul mudah dipahami & $77 \%$ & Layak \\
\hline Teks dalam e-modul mudah dibaca dengan jelas & $70,4 \%$ & Layak \\
\hline $\begin{array}{l}\text { Penggunaan media gambar dalam e-modul sesuai dengan } \\
\text { materi pelajaran }\end{array}$ & $59,3 \%$ & Cukup Layak \\
\hline $\begin{array}{l}\text { Penggunaan font dan warna dalam e-modul tepat dan tidak } \\
\text { merusak sajian materi }\end{array}$ & $80 \%$ & Layak \\
\hline Setiap langkah pembelajaran di dalam e-modul jelas & $50 \%$ & Cukup Layak \\
\hline $\begin{array}{l}\text { Tugas yang diberikan dalam kegiatan pembelajaran E-modul } \\
\text { jelas sesuai dengan materi pelajaran }\end{array}$ & $74,1 \%$ & Layak \\
\hline $\begin{array}{l}\text { Dengan adanya e-modul, saya lebih termotivasi untuk } \\
\text { mengerjakan soal-soal latihan pada e-modul dengan benar dan } \\
\text { tepat }\end{array}$ & $66,7 \%$ & Layak \\
\hline $\begin{array}{l}\text { Saya memperoleh pengetahuan baru setelah mengikuti } \\
\text { pembelajaran menggunakan e-modul }\end{array}$ & $70,4 \%$ & Layak \\
\hline $\begin{array}{l}\text { Saya mendukung e-modul pada pembelajaran selanjutnya } \\
\text { (Sumber: Diolah Peneliti, 2021) }\end{array}$ & $62 \%$ & Layak \\
\hline
\end{tabular}

Hasil dari angket respons peserta didik ialah tanggapan dari pengembangan e-modul berbasis flipbook maker pada mata pelajaran teknologi perkantoran. Setelah melakukan proses penyebaran angket kepada 24 peserta didik siswa kelas X OTKP 1 SMKN 1 Sooko Mojokerto untuk mengetahui hasil dari pengembangan e-modul berbasis flipbook maker pada mata pelajaran teknologi perkantoran memperoleh rata-rata 95,45\% dengan kategori sangat layak. Penelitian serupa oleh Anggraini, dkk (2016) menunjukkan persentase sebesar 96,6\%. Pengembangan e-modul berbasis flipbook maker pada mata pelajaran teknologi perkantoran sangat layak serta dapat meningkatkan motivasi belajar untuk peserta didik dan sangat membantu saat kegiatan belajar berlangsung. Hal ini selaras dengan penelitian (Amanullah, 2020), yang menyatakan bahwa dengan adanya pengembangan e-modul berbasis flipbook maker pada mata pelajaran teknologi perkantoran dapat memaksimalkan kegiatan belajar berlangsung di dalam kelas dan dapat membantu peserta didik dalam kegiatan pembelajaran berlangsung yang disajika oleh guru. Penelitian yang serupa yaitu oleh (Damarsasi, D\&G., \& Saptorini, 2018) juga menyatakan bahwa e-modul berbasis flipbook maker dapat meningkatkan hasil belajar peserta didik. Jadi dapat dikatakan bahwa e-modul berbasis flipbook maker pada mata pelajaran teknologi perkantoran sangat layak digunakan sebagai bahan ajar di SMKN 1 Sooko Mojokerto.

\section{KESIMPULAN}

Berdasarkan hasil penelitian yang menghasilkan produk pengembangan e-modul pada Teknologi Perkantoran di kelas X jurusan OTKP di SMKN 1 Sooko, Mojokerto dinilai sangat layak. Dengan model ADDIE (Analisis, Desain, Pengembangan, Implementasi, dan Evaluasi), modul digital ini berguna bagi guru dan siswa. Hasil validasi dari para ahli materi memperoleh rata-rata 85\% dengan kategori sangat layak. Kedua, dari ahli media memperoleh rata-rata 92\% dengan kategori sangat layak. Ketiga, dari ahli bahasa memperoleh rata-rata $88 \%$ dengan kategori sangat layak. Kemudian, siswa merespons baik adanya e-modul ini dengan baik dengan persentase rata-rata 95,45\%. Penelitian ini membahas permasalahan pada pengembangan $e$-modul berbasis flipbook maker pada mata pelajaran teknologi perkantoran. Sebagai penutup, e-modul ini layak digunakan sebagai bahan ajar pada mata pelajaran teknologi perkantoran kelas X OTKP 1 dapat digunakan untuk bahan ajar di SMKN 1 Sooko Mojokerto. 
3738 Pengembangan E-Modul Berbasis Flipbook Maker pada Mata Pelajaran Teknologi Perkantoran - Ferlinda Herdianti Widiana, Brillian Rosy

DOI: https://doi.org/10.31004/edukatif.v3i6.1265

\section{DAFTAR PUSTAKA}

Amanullah, M. . (2020). Pengembangan Media Pembelajaran Flipbook Digital Guna Menunjang Proses Pembelajaran Di Era Revolusi Industri 4.0. Jurnal Dimensi Pendidikan Dan Pembelajaran.

Anggraini, Dkk. (2016). Pegembangan Bahan Ajar Materi Trigonometri Berbantuan Software Imindmap Pada Siswa SMA. Al-Jabar : Jurnal Pendidikan Matematika, 7(1), 39-47.

Arsyad. (2017). Media Pembelajaran. Raja Grafindo Persada.

Asmi, A. R., Surbakti, A. N. D., \& C., H. (2018). Pengembangan E-Modul Berbasis Flip Book Maker Materi. Jurnal Pendidikan Ilmu Sosial, 27, 1-10.

Citra, C. A., \& Rosy, B. (2020). Keefektifan Penggunaan Media Pembelajaran Berbasis Game Edukasi Quizizz Terhadap Hasil Belajar Teknologi Perkantoran Siswa Kelas X SMK Ketintang Surabaya. Jurnal $\begin{array}{lllll}\text { Pendidikan Administrasi } & \text { Perkantoran } & \text { (JPAP), } & 8, & \text { 261-272. }\end{array}$ Https://Journal.Unesa.Ac.Id/Index.Php/Jpap/Article/View/8242/4081

Damarsasi, D\&G., \& Saptorini, S. (2018). Pengembangan E-Modul Berbasis Flipbook Maker Materi. Jurnal Pendidikan Ilmu Sosial, 27, 1-10.

Fausih, M., \& Danang, T. (2015). Pengembangan Media E-Modul Mata Pelajaran Produktif Pokok Bahasan "Instalasi Jaringan Lan (Local Area Network)" Untuk Siswa Kelas Xi Jurusan Teknik Komputer Jaringan Di Smk Nengeri 1 Labang Bangkalan Madura. Jurnal UNESA, 01(01), 1-9. Https://Jurnalmahasiswa.Unesa.Ac.Id/Index.Php/Jmtp/Article/View/10375

Fitrayani Hunaepi. (2016). Pengembangan Modul Elektronik Berbasis Smartphone Berplatform Android Pada Matakuliah Taksonomi Tumbuhan Tinggi,. 4(2), 97-106.

Fitri Nurmayanti, Fauzi Bakri, Dan E. B. (2015). Pengembangan Modul Elektronik Fisika Dengan Strategi PDEODE Pada Pokok Bahasan Teori Kinetik Gas Untuk Siswa Kelas XI SMA. Prosiding Simposium Nasional Inovasi Dan Pembelajaran Sains, 2015(Snips), 337.

Gunadharma. (N.D.). No Titlepengembangan Modul Elektronik Sebagai Sumber Belajar Untuk Mata Kuliah Multimedia Design. Jurnal Pendidikan Teknologi Dan Kejuruan,. (1), 3.

Hanafy, M. S. (2014). Konsep Belajar Dan Pembelajaran. Lentera Pendidikan : Jurnal Ilmu Tarbiyah Dan Keguruan, 17(1), 66-79. Https://Doi.Org/10.24252/Lp.2014v17n1a5

Ihsan. (2014). Pegembangan Modul Elektronik Microsoft Excel 2007 Untuk Kelas XI Sekolah Menengah Atas.

Karno, R. (2015). Penerapan Media Pembelajaran Biologi Dengan Menggunakan Macromedia Flash Profesional 8. Jurnal Ilmiah Edu Research, 4(1), 79-84. Http://EJournal.Upp.Ac.Id/Index.Php/EDU/Article/View/1198

Magdalena, I., Sundari, T., Nurkamilah, S., Nasrullah, \& Amalia, D. A. (2020). Analisis Bahan Ajar. Nusantara : Jurnal Pendidikan Dan Ilmu Sosial, 2(2), 311-326.

Pane, A., \& Darwis Dasopang, M. (2017). Belajar Dan Pembelajaran. FITRAH:Jurnal Kajian Ilmu-Ilmu Keislaman, 3(2), 333. Https://Doi.Org/10.24952/Fitrah.V3i2.945

Praspita, R., \& Rosy, B. (2020). Pengembangan Lembar Kegiatan Peserta Didik Berbasis Pendekatan Saintifik Pada Mata Pelajaran Administrasi Umum Di Kelas X OTKP 1 SMK Negeri 1 Tuban. Jurnal Pendidikan Administrasi Perkantoran (JPAP), 8(3), 504-515.

Prastowo, A. (2015). Panduan Kreatif Membuat Bahan Ajar Inovatif. Diva Press.

Putra, R. W. Y., \& Anggraini, R. (2016). Pengembangan Bahan Ajar Materi Trigonometri Berbantuan Software Imindmap Pada Siswa SMA. Al-Jabar: Jurnal Pendidikan Matematika, 7(1), 39-47.

Putry Widyaningrum, F. D. P. (2021). Pengembangan E-Modul Dengan Flipbook Maker KD 3.6 Menganalisis Perilaku Konsumen Dalam Bisnis Ritel Kelas XI BDP Di SMK Negeri 2 Tuban. Tata Niaga (JPTN), 9(1), 1048-1054. 
3739 Pengembangan E-Modul Berbasis Flipbook Maker pada Mata Pelajaran Teknologi Perkantoran - Ferlinda Herdianti Widiana, Brillian Rosy

DOI: https://doi.org/10.31004/edukatif.v3i6.1265

Rahim A., J. Dan S. N. (2017). Pengembangan Modul Elektronik Berbasis Discovery Learning Menggunakan 3D Pageflip Professional Pada Materi Gerak Lurus Untuk Kelas X SMA. Artikel Ilmiah.

Rahmi, L. (2018). Perancangan E-Module Perakitan Dan Instalasi Personal Komputer Sebagai Media Pembelajaran Siswa SMK. TA 'DIB, 21(2), 105-111.

Ricu Sidiq, \& Najuah. (2020). Pengembangan E-Modul Interaktif Berbasis Android Pada Mata Kuliah Strategi Belajar Mengajar. Jurnal Pendidikan Sejarah, 9(1), 1-14. Https://Doi.Org/10.21009/Jps.091.01

Riduwan. (2015). Skala Pengukuran Variabel-Variabel Penelitian. In Skala Pengukuran Variabel-Variabel Penelitian. Alfabeta.

Sadiman, A. (2014). Media Pendidikan Pengertian Pengembangan Dan Pemanfaatannya. Rajawali Pers.

Sugianto, D., Abdullah, A. G., Elvyanti, S., \& Muladi, Y. (2013). MODUL VIRTUAL: MULTIMEDIA FLIPBOOK DASAR TEKNIK DIGITAL. IX(2), 101-116.

Sugiyono. (2016). Metode Penelitian Kuantitatif, Kualitatif, Dan R\&D. Alfabeta.

Susilo, A., Siswandari, \& Bandi. (2016). Pengembangan Modul Berbasis Pembelajaran Saintifik Untuk Peningkatan Kemampuan Mencipta Siswa Dalam Proses Pembelajaran Akuntansi Siswa Kelas XII SMAN 1 Slogohimo 2014. Jurnal Pendidikan Ilmu Sosial, 26(1), 50-56.

Syidiq \& Najuah. (2020). Pengembangan E-Modul Interaktif Berbasis Android Pada Mata Kuliah Strategi Belajar Mengajar. Jurnal Pendidikan Sejarah, $9(1), \quad 1-14$. Https://Doi.Org/Https://Doi.Org/10.21009/Jps.091.01 